\title{
The bacteriology of biopsies differs between newly diagnosed, untreated, Crohn's disease and ulcerative colitis patients
}

\begin{abstract}
Correspondence
G. W. Tannock

gerald.tannock@stonebow.

otago.ac.nz
\end{abstract}

Received 4 January 2006

Accepted 18 April 2006

\author{
Rodrigo Bibiloni, ${ }^{1}$ Marco Mangold, ${ }^{2}$ Karen L. Madsen, ${ }^{3}$ Richard N. Fedorak ${ }^{3}$ \\ and Gerald W. Tannock ${ }^{1,2}$
}

1,2Department of Agricultural, Food and Nutritional Science ${ }^{1}$ and Department of Microbiology
and Immunology 2 , University of Otago, PO Box 56, Dunedin, New Zealand

${ }^{3}$ Department of Medicine, University of Alberta, Edmonton, Canada

\section{INTRODUCTION}

Crohn's disease (CD) and ulcerative colitis (UC) are considered to be distinct clinical entities that have in common an inappropriate, exaggerated and ongoing activation of the mucosal immune system that is fuelled by the presence of the bacterial collection (gut microbiota) normally resident in the intestinal tract. This pathological response is likely to be associated with defects in epithelial barrier function and of the immune system, which are, in part, genetically determined (Podolsky, 2002; Bouma \& Strober, 2003). Several bacterial and viral pathogens have been suggested as causes of inflammatory bowel diseases (IBDs), but none has

Abbreviations: CD, Crohn's disease; DGGE, denaturing gradient gel electrophoresis; IBD, inflammatory bowel disease; OTU, operational taxonomic unit; UC, ulcerative colitis. gained general acceptance. Rather than specific pathogens, current views favour members of the gut microbiota as the source of antigens with which the dysfunctional immune system reacts (Schultz \& Rath, 2002). Determining whether certain members of the microbiota, or the microbial collection en masse, are responsible for the abnormal microbeimmune system interplay is not a simple process. The analysis of the gut microbiota of humans has been fraught with difficulties due to an inability to culture most of the bacterial inhabitants of the gut. Perhaps as much as $60 \%$ of the gut microbiota has not yet been cultivated in the laboratory, even when state-of-the-art bacteriological methods have been used (Tannock et al., 2000). Analysis of the faecal microbiota in relation to IBDs has been attempted (Ruseler-Van Embden \& Both-Patoir, 1983; Seksik et al., 2003), which although representative of the microbiota in 
the distal colon (Moore et al., 1978), does not necessarily provide information that is relevant to the region of the bowel where disease is present (Zoetendal et al., 2002). Biopsies collected at endoscopy provide samples pertinent to the study of the diseased site. They are not perfect for microbiological analysis because they consist of only a few milligrams of tissue and have been collected from subjects that have undergone bowel cleansing prior to endoscopy. Nevertheless, as has been demonstrated by others, the presence of small numbers of bacteria associated with biopsies can be detected by nucleic-acid-based analytical methods and useful contributions to knowledge can be obtained (Schultsz et al., 1999; Swidsinski et al., 2002; Ott et al., 2004; Prindiville et al., 2004; Lepage et al., 2005). Usually, however, the human subjects that have been studied have already received treatment for their medical conditions, which might have influenced the analytical outcomes.

We have studied the numbers and types of bacteria associated with biopsies collected from intestinal sites of newly diagnosed and untreated CD and UC patients. Nucleic-acidbased methods of analysis were used in order to overcome the problem of non-cultivability of bacterial members of the microbiota. The results of the analyses show that UC and CD are bacteriologically distinct diseases.

\section{METHODS}

Sample collection. Intestinal biopsies were obtained from the Canadian IBD Network Tissue Bank established by the Crohn's and Colitis Foundation of Canada (Collins et al., 2003). The biopsies were collected during endoscopy, after standard bowel cleansing methods, of patients at Canadian institutions and were stored at $-70{ }^{\circ} \mathrm{C}$ until diagnosis was made. The samples were curated by Gamma Dynacare Medical Laboratories before shipment on dry ice to the analytical laboratory at the University of Alberta, Edmonton. The approval of ethics committees at institutions involved in collecting samples was obtained and the laboratory manipulations were approved by the Agriculture, Forestry and Home Economics Research Ethics Board (permit 0302) at the University of Alberta.

Patients were included in the study if they had clinically active UC or CD. Diagnosis was confirmed by endoscopy and histology by pathologists at the participating institutions. The patients were newly diagnosed and none had received antibiotics, immunosuppressives or glucocorticosteroids prior to endoscopy. Biopsies were obtained during endoscopy from inflamed and non-inflamed gut regions of 15 patients with UC and 20 patients with CD. Tissue was considered normal if there was an absence of macroscopic or histological evidence of inflammation. Three biopsy pieces taken from each site (range $3 \cdot 2-30 \cdot 5 \mathrm{mg}$; mean $14 \cdot 3 \mathrm{mg}$ ) were pooled for analysis. Three biopsy pieces (range $4.6-25 \cdot 0 \mathrm{mg}$; mean $11.6 \mathrm{mg}$ ) were also collected from five intestinal sites (terminal ileum, right colon, transverse colon, left colon, rectum) of 14 non-matched patients, subsequently termed healthy subjects, who were undergoing routine diagnostic workup or had a family history of colon cancer. They did not have mucosal abnormalities of the terminal ileum, colon or rectum. Relevant details of patients and healthy subjects are summarized in Table 1, and the sites from which biopsies were collected are shown in Table 2.

Bacterial strains. DNA extracted from the following bacterial strains was used as positive controls in PCR detection of specific bacterial groups: Bacteroides vulgatus ATCC 29327, Bifidobacterium
Table 1. Human subjects

\begin{tabular}{|lccc|}
\hline & $\begin{array}{c}\text { Healthy } \\
\text { subjects }\end{array}$ & $\begin{array}{c}\text { CD } \\
\text { patients }\end{array}$ & $\begin{array}{c}\text { UC } \\
\text { patients }\end{array}$ \\
\hline Males/females & $3 / 11$ & $12 / 8$ & $7 / 8$ \\
Age (years) & $47(12-73)^{*}$ & $22(12-56)$ & $24(11-53)$ \\
Smokers $\dagger$ & $2 / 4 / 8$ & $3 / 3 / 14$ & $0 / 2 / 13$ \\
Birth control pill $\dagger$ & $1 / 4 / 9$ & $1 / 2 / 17$ & $3 / 1 / 11$ \\
Aspirin $\dagger$ & $4 / 2 / 8$ & $0 / 1 / 19$ & $0 / 3 / 12$ \\
NSAID $\dagger \ddagger$ & $1 / 3 / 10$ & $1 / 2 / 17$ & $1 / 3 / 11$ \\
& & & \\
\hline
\end{tabular}

${ }^{\star}$ Mean (range).

$\dagger$ Currently/previously/never. Previously indicates former use but ceased at least 1 year previously.

$\ddagger$ Non-steroidal anti-inflammatory drugs (ibuprofen, naproxen or similar).

adolescentis DSM 20083 ${ }^{\mathrm{T}}$, Clostridium difficile DSM $1296^{\mathrm{T}}$, Clostridium coccoides ATCC $29236^{\mathrm{T}}$, Helicobacter pylori DSM 7492, Lactobacillus ruminis ATCC $27780^{\mathrm{T}}$ and Desulfovibrio desulfuricans isolated from the faeces of an ankylosing spondylitis patient (Stebbings et al., 2002). Mycobacterium avium subsp. paratuberculosis $316 f$ (Thorel et al., 1990) DNA was a gift from the Disease Research Laboratory, University of Otago.

Nucleic acid extraction. In the case of biopsies, DNA was extracted from the samples using the Qiagen DNA/RNA Extraction kit. Biopsies were not washed prior to analysis. The three biopsy pieces from each site were pooled and placed in $300 \mu \mathrm{l}$ lysozyme solution $\left(30 \mathrm{mg} \mathrm{ml}^{-1}\right)$ and vortexed every $10 \mathrm{~min}$ during a $30 \mathrm{~min}$ period at room temperature. After the addition of $500 \mu \mathrm{l}$ QRL1 buffer supplemented with 2-mercaptoethanol, samples were shaken at 5000 r.p.m. in a bead-beater for $2 \mathrm{~min}$. QRV1 buffer $(300 \mu \mathrm{l})$ was added to the tubes, and samples were vortexed and centrifuged at $15000 \mathrm{~g}$ for $20 \mathrm{~min}$. The supernatant was recovered, $800 \mu \mathrm{l}$ isopropanol was added, and the supernatant was stored overnight at

Table 2. Sites from which biopsies were collected

Abbreviations: TI, terminal ileum; RC, right colon; TC, transverse colon; LC, left colon; REC, rectum. Biopsies were obtained from all five sites from healthy subjects. Values show the number of patients.

\begin{tabular}{|lccc|}
\hline $\begin{array}{l}\text { Patient } \\
\text { group }\end{array}$ & $\begin{array}{c}\text { Site } \\
\text { sampled }\end{array}$ & $\begin{array}{c}\text { Inflamed } \\
\text { mucosa }\end{array}$ & $\begin{array}{c}\text { Non-inflamed } \\
\text { mucosa }\end{array}$ \\
\hline CD & TI & 4 & 2 \\
& RC & 7 & 6 \\
& TC & 0 & 1 \\
& LC & 0 & 2 \\
& REC & 9 & 9 \\
UC & TI & 0 & 2 \\
& RC & 0 & 10 \\
& TC & 2 & 2 \\
& LC & 0 & 0 \\
\hline
\end{tabular}


$-20{ }^{\circ} \mathrm{C}$. DNA pellets were recovered by centrifugation at $15000 \mathrm{~g}$ for $30 \mathrm{~min}$ and dissolved in $150 \mu \mathrm{l}$ QRL1 buffer (supplemented with 2-mercaptoethanol) at $60^{\circ} \mathrm{C}$. After the addition of $1.35 \mathrm{ml}$ QRV2 buffer, the preparation was centrifuged at $5000 \mathrm{~g}$ for $5 \mathrm{~min}$ at $4{ }^{\circ} \mathrm{C}$, then the supernatant was loaded onto a separation column equilibrated with QRE solution. The flow-through was recovered and reloaded onto the column and drained by gravity. The column was washed three times with QW buffer, and DNA was eluted with QF buffer at $45{ }^{\circ} \mathrm{C}$ and precipitated with $700 \mu \mathrm{l}$ isopropanol at $-20^{\circ} \mathrm{C}$. The DNA preparations were centrifuged at $15000 \mathrm{~g}$ for $30 \mathrm{~min}$ at $4{ }^{\circ} \mathrm{C}$, and the pellets were washed twice with $500 \mu \mathrm{l} 80 \%$ cold ethanol $\left(-20^{\circ} \mathrm{C}\right)$. The DNA extracts were stored at $-80^{\circ} \mathrm{C}$ until further analysis. DNA integrity was assessed by electrophoresis of each sample in a $1.2 \%$ agarose gel that was stained with ethidium bromide solution $\left(5 \mu \mathrm{g} \mathrm{ml}^{-1}\right)$ and viewed by UV transillumination.

DNA was extracted from PCR control bacteria by harvesting cells grown on agar plates, suspension in sterile deionized water, and centrifugation at $10000 \mathrm{~g}$ for $15 \mathrm{~min}$. The cells were washed twice with TN150 buffer $(10 \mathrm{mM}$ Tris/HCl, pH $8,150 \mathrm{mM} \mathrm{NaCl})$ and resuspended in $1 \mathrm{ml}$ of the same buffer. Samples were disrupted in a bead-beater for $3 \mathrm{~min}$ at 5000 r.p.m., then centrifuged at $14000 \mathrm{~g}$ for $5 \mathrm{~min}$ at $5{ }^{\circ} \mathrm{C}$. DNA was purified from supernatants by phenol/ chloroform extraction and sodium acetate/ethanol precipitation, as described previously (Tannock et al., 2000).

\section{Denaturing gradient gel electrophoresis (DGGE) profiles of biopsy-associated bacteria. Bacterial DNA was amplified by PCR targeting the $\mathrm{V} 3$ region of the $16 \mathrm{~S}$ rRNA gene using the universal bacterial primers HDA1-GC and HDA2, and a previously described programme (Tannock et al., 2000). PCR products were checked before DGGE analysis by electrophoresis in a $2 \%$ agarose gel stained with ethidium bromide $\left(5 \mu \mathrm{g} \mathrm{ml}^{-1}\right)$ and viewed by UV transillumi- nation. Electrophoresis was performed using a DCode apparatus (Bio-Rad) and $6 \%$ polyacrylamide gels with a $30-55 \%$ gradient of $7 \cdot 0 \mathrm{M}$ urea and $40 \%(\mathrm{v} / \mathrm{v})$ formamide that increased in the direc- tion of electrophoresis. Electrophoretic runs were in TAE buffer (40 mM Tris, $20 \mathrm{mM}$ acetic acid, $1 \mathrm{mM}$ EDTA) at $130 \mathrm{~V}$ and $60^{\circ} \mathrm{C}$ for $275 \mathrm{~min}$. Gels were stained with ethidium bromide solution $\left(5 \mu \mathrm{g} \mathrm{ml}^{-1}\right)$ for $20 \mathrm{~min}$, washed with deionized water for $20 \mathrm{~min}$, and viewed by UV transillumination. DGGE profiles were com- pared by determining the Dice similarity coefficient $\left(D_{\mathrm{sc}}\right)$ using the Bionumerics software package (version 3.0, Applied Maths) at a sen- sitivity of $2-3 \%$.}

Detection of selected bacterial groups by PCR. PCR detection of selected bacterial groups utilized a GeneAmp PCR System 9700 thermocycler (Applied Biosystems). The PCR reaction mixture (50 $\mu$ l volume) contained $1.5 \mathrm{mM} \mathrm{MgCl}_{2}, 50 \mathrm{mM} \mathrm{KCl}, 20 \mathrm{mM}$ Tris/ $\mathrm{HCl}(\mathrm{pH} 8 \cdot 4)$, deoxynucleoside triphosphates at a concentration of $200 \mu \mathrm{M}$ each, $20 \mathrm{pM}$ each primer (Table 3), 2.5 U Taq DNA polymerase (Invitrogen) and $2 \mu \mathrm{l}$ biopsy DNA. Five-microlitre aliquots of the PCR product were electrophoresed in a $2 \%$ agarose gel, which was stained with ethidium bromide and viewed by UV transillumination. The size of the products was confirmed by reference to a DNA molecular mass ladder (Invitrogen) and by cloning and sequencing.

Preparation of 165 rRNA gene clone libraries. Universal bacterial primers, SacI-POmod (Escherichia coli position 11) and HDA2 (E. coli position 539) (Rodtong \& Tannock, 1993; Tannock et al., 2000) were used to generate a partial sequence of 16 S rRNA genes (528 bp). PCR was performed using the reaction mixture described above for other PCR analyses, and the following programme: $95^{\circ} \mathrm{C}$ for $4 \mathrm{~min}$, followed by 25 cycles $1 \mathrm{~min}$ at $95^{\circ} \mathrm{C}, 1 \mathrm{~min}$ at $58^{\circ} \mathrm{C}$, $2 \mathrm{~min}$ at $72^{\circ} \mathrm{C}$, then $72^{\circ} \mathrm{C}$ for $7 \mathrm{~min}$. The least number of cycles was used to minimize preferential amplification of sequences that would create bias. The $16 \mathrm{~S}$ rRNA gene amplicons were cloned in the
pCR2.1 TOPO plasmid vector (Invitrogen), and One Shot Top10 (Invitrogen) competent E. coli cells were chemically transformed as described by the supplier. Recombinant cells were cultured on Luria-Bertani (LB; Becton Dickinson) agar plates containing $100 \mu \mathrm{g}$ ampicillin $\mathrm{ml}^{-1}$ (Sigma) and $40 \mu \mathrm{g} \mathrm{X}-\mathrm{Gal} \mathrm{ml}^{-1}$ (Sigma). Sixty white colonies from each transformation reaction were picked randomly with sterile toothpicks and transferred to a second plate of LB agar plus ampicillin/X-Gal to confirm the colour selection. Forty-eight white colonies from the second plate were each transferred to individual wells of a 96-well microtitre tray, each well containing $200 \mu \mathrm{l}$

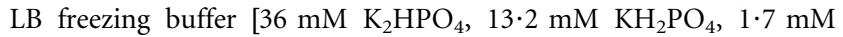

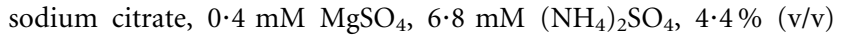
glycerol, LB broth] (Zimmer \& Gibbins, 1997). The plates were incubated at $37^{\circ} \mathrm{C}$ overnight to allow proliferation of the cells, then duplicated and stored at $-80^{\circ} \mathrm{C}$ until further analysis. Cloned $16 \mathrm{~S}$ rRNA gene sequences were amplified using plasmid-targeted primers (M13 forward, 5'-GTAAAACGACGGCCAG-3', and M13 reverse, 5'-CAGGAAACAGCTATGAC-3') and the following PCR programme: $94^{\circ} \mathrm{C}$ for $4 \mathrm{~min}$, followed by 25 cycles $94{ }^{\circ} \mathrm{C}$ for $1 \mathrm{~min}$, $56^{\circ} \mathrm{C}$ for $1 \mathrm{~min}, 72{ }^{\circ} \mathrm{C}$ for $2 \mathrm{~min}$, then $72{ }^{\circ} \mathrm{C}$ for $7 \mathrm{~min}$. The size of the PCR products was confirmed by agarose gel electrophoresis with molecular mass marker, as described above. Amplified DNA ( $4 \mu \mathrm{l})$ was used as template for sequencing. The dideoxy chain-termination reaction was conducted using the M13 reverse primer, the CEQ DTCS kit (Beckman Coulter) and the CEQ8000 Genetic Analyser (Beckman Coulter) following the manufacturer's instructions. Sequences were edited to $515 \mathrm{bp}$ using EditSeq software (DNASTAR). Each biopsy sample contributed, on average, 27 clones per library, which approximately matched the average number of intensely stained 16S rRNA gene fragments per DGGE profile. The library prepared from healthy subjects was composed of sequences generated from biopsies collected from the right colon.

Comparison of 16S rRNA gene clone libraries. The libraries prepared from 16S rRNA genes of bacteria associated with inflamed and non-inflamed biopsies obtained from CD and UC patients, and biopsies of healthy subjects, were compared using webLIBSHUFF version 0.95 (http://libshuff.mib.uga.edu), the web interface for the LIBSHUFF (LIBrary SHUFFling) program version 1.22. The program provides a statistical test for the null hypothesis that two 16S rRNA gene libraries are samples of the same prokaryotic community. Significantly different libraries are assumed to have been derived from communities of different composition. The program is based on the work of Singleton et al. (2001).

Assessment of the richness of the collection of bacteria associated with biopsy samples obtained from CD, UC and healthy subjects was made using the DOTUR (distance-based OTU and richness) program (http://www.plantpath.wisc.edu/fac/joh/DOTUR.html), which assigns sequences to operational taxonomic units (OTUs, molecular species). OTUs are defined as containing sequences that are more than $3 \%$ different from each other. The Shannon index is a sensitive measure of community richness and can be calculated using the DOTUR software (Hughes \& Bohannan, 2004). The program is based on the work of Schloss and Handelsman (2005).

Coverage of the bacterial collections associated with biopsies was calculated by the method of Good (1953), according to which the percentage of coverage was calculated using the formula $[1-(n / N)] \times$ 100 , where $n$ is the number of molecular species represented by one clone (single-clone OTU) and $N$ is the total number of sequences in the library.

Library sequences were classified using the Library Compare Tool provided by the Ribosomal Database Project (RDP; http://rdp.cme. msu.edu/comparison/comp.jsp). The tool uses the RDP naïe Bayesian classifier, 2003, version 1.0 to provide rapid classification of library 
Table 3. Detection of specific bacteria by PCR

\begin{tabular}{|c|c|c|c|}
\hline Bacterial group & Primer and sequence $\left(5^{\prime} \rightarrow 3^{\prime}\right)$ & Amplicon size & $\begin{array}{l}\text { PCR programme } \\
\text { reference }\end{array}$ \\
\hline Bacteroides/Prevotella group & $\begin{array}{l}\text { Bac32F: AACGCTAGCTACAGGCTT } \\
\text { Bac303R: CAAATGTGGGGGACCTTC }\end{array}$ & $276 \mathrm{bp}$ & Bernhard \& Field (2000) \\
\hline Bifidobacterium sp. & $\begin{array}{l}\text { Bif164: GGGTGGTAATGCCGGATG } \\
\text { Bif662: CCACCGTTACACCGGGAA }\end{array}$ & $523 \mathrm{bp}$ & Kok et al. (1996) \\
\hline C. coccoides group & $\begin{array}{l}\text { gCcoc-F: AAATGACGGTACCTGACTAA } \\
\text { gCcoc-R: CTTTGAGTTTCATTCTTGCGAA }\end{array}$ & $438-441$ bp & Matsuki et al. (2002) \\
\hline C. difficile & $\begin{array}{l}\text { KAG1: CTCGCATATAGCATTAGACCA } \\
\text { KAG2: CATGGGATAGATATCAGGGC } \\
\text { KAG4: ATTTCCCAACGGTCTAGTCC }\end{array}$ & $\begin{array}{l}\text { KAG1/KAG4, } 905 \text { bp; } \\
\text { KAG2/KAG4, } 236 \text { bp }\end{array}$ & Dove et al. (1990) \\
\hline Helicobacter sp. & $\begin{array}{l}\text { H276F: TATGACGGGTATCCGGC } \\
\text { H676R: ATTCCACCTACCTCTCCCA }\end{array}$ & 375 bp & Beckwith et al. (1997) \\
\hline Lactic acid bacteria & $\begin{array}{l}\text { Lac1: AGCAGTAGGGAATCTTCCA } \\
\text { Lac2: ATTYCACCGCTACACATG }\end{array}$ & $340 \mathrm{bp}$ & Walter et al. (2001) \\
\hline $\begin{array}{l}\text { M. avium subsp. } \\
\text { paratuberculosis }\end{array}$ & $\begin{array}{l}\text { p89: CGTCGGGTATGGCTTTCATGTGGTTGCTGTG } \\
\text { p92: CGTCGTTGGCCACCCGCTGCGAGAGCAAT }\end{array}$ & 284 bp & Sechi et al. (2001) \\
\hline & $\begin{array}{l}\text { p90: GTTCGGGGCCGTCGCTTAGG } \\
\text { p91: GAGGTCGATCGCCCACGTGA } \\
\text { AV1: ATGTGGTTGCTGTGTTGGATGG } \\
\text { AV2: CCGCCGCAATCAACTCCAG }\end{array}$ & $\begin{array}{l}\text { p90/p91, } 398 \text { bp; } \\
\text { AV1/AV2, } 298 \text { bp }\end{array}$ & Naser et al. (2004) \\
\hline $\begin{array}{l}\text { Sulfate-reducing } \\
\text { bacteria }\end{array}$ & $\begin{array}{l}\text { APS-FW: TGGCAGATMATGATYMACGGG } \\
\text { APS-RV: GGGCCGTAACCGTCCTTGAA }\end{array}$ & $396 \mathrm{bp}$ & Deplancke et al. (2000) \\
\hline $\begin{array}{l}\text { Universal bacterial } \\
\text { primers, real-time } \\
\text { quantitative PCR }\end{array}$ & $\begin{array}{l}\text { UniBac1 for: TCCTACGGGAGGCAGCAGT } \\
\text { UniBac2 rev: GGACTACCAGGGTATCTAATCCTGTT }\end{array}$ & $466 \mathrm{bp}$ & Nadkarni et al. (2002) \\
\hline
\end{tabular}

sequences into the bacterial taxonomy. The classifier is trained mostly on known type-strain rRNA sequences. Each library sequence is assigned to a set of hierarchical taxa from phylum to genus rank, along with a confidence estimate for each assignment. The current hierarchy model used by the naïve Bayesian rRNA classifier comes from that proposed in the 2004 release of Bergey's Manual of Systematic Bacteriology (http://bergeysoutline.com).

Measurement of bacterial cell numbers associated with biopsies by real-time quantitative PCR. Because of the variation in biopsy size and weight, the unknown amounts of mucus associated with each biopsy, and the preponderance of human relative to bacterial nucleic acid in DNA extracts of biopsies, we standardized comparison of the numbers of bacteria associated with biopsies by determining the ratio of $E$. coli equivalents to the number of $\beta$-actin equivalents (human cells). The number of bacteria ( $E$. coli equivalents) associated per human cell (human $\beta$-actin equivalents) was measured by reference to standard DNA curves generated from known numbers of E. coli DH5 $\alpha$ and HEp-2 cells, respectively. Cells in an E. coli culture in LB broth were enumerated by plating aliquots of 10 -fold dilutions on agar plates, which were incubated for $24 \mathrm{~h}$ at $37^{\circ} \mathrm{C}$, after which the remainder of the cells in the culture were used to extract DNA, as described above. This provided a DNA sample which was then subjected to 10 -fold dilutions to generate samples equivalent to $4 \cdot 5 \times 10^{7}-4 \cdot 5 \times 10^{1}$ E. coli cells $\mathrm{ml}^{-1}$. HEp-2 cells were harvested from cultures prepared in RPMI 1640 medium (GibcoBRL), and counted microscopically. DNA was extracted from the cells as described for E. coli, and dilutions were prepared equivalent to $2 \cdot 1 \times 10^{6}-2 \cdot 1 \times 10^{1}$ cells. Real-time quantitative PCR was performed using an Applied Biosystems 7900HT Fast Real-Time PCR system. Each PCR reaction, in duplicate, consisted of $12 \cdot 5 \mu \mathrm{l}$ SYBR Green PCR Master Mix (Applied Biosystems), $300 \mathrm{nM}$ each primer in the case of bacterial detection (Table 3) or $0.5 \mu \mathrm{M}$ of primers for the detection of the human $\beta$-actin gene (Stratagene), and $1 \mu \mathrm{l}$ template DNA, brought to a final volume of $25 \mu \mathrm{l}$ with sterile deionized water. The amplification programme was $50^{\circ} \mathrm{C}$ for $2 \mathrm{~min}, 95^{\circ} \mathrm{C}$ for $10 \mathrm{~min}$, followed by 40 cycles of $95^{\circ} \mathrm{C}$ for $15 \mathrm{~s}$, $60{ }^{\circ} \mathrm{C}$ for $60 \mathrm{~s}$, and a final stage of $95^{\circ} \mathrm{C}$ for $15 \mathrm{~s}, 60^{\circ} \mathrm{C}$ for $60 \mathrm{~s}$ and $95^{\circ} \mathrm{C}$ for $15 \mathrm{~s}$. Numerical values of E. coli equivalents and human $\beta$-actin equivalents were used to plot standard curves, from which the relative number of bacteria per human cell associated with biopsy samples was calculated.

Statistical tests. Tests used in the comparison of 16S rRNA gene clone libraries are given above. Other statistical analyses were Fisher's exact test, the Mann-Whitney non-parametric test, and KruskalWallis non-parametric ANOVA. 


\section{RESULTS}

\section{Comparison of PCR/DGGE profiles}

The 16S rRNA gene profiles of the bacterial collections associated with biopsies were generated by PCR coupled with DGGE. Examples of profiles are shown in Fig. 1. There was an average of 25 intensely stained DNA fragments per profile, regardless of intestinal region or subject group. To gain insight into the constancy of biopsy-associated bacterial profiles in the distal intestinal tract, the Dice similarity coefficient (tolerance 2-3\%) was determined from comparison of four to five regions of the intestine of 12 healthy subjects. The biopsy-associated bacterial profiles were very similar within individual subjects (mean $85.0 \%$, SEM $2 \cdot 4 \%$ ). Comparisons made between individuals showed that the profiles were much less similar (terminal ileum $71 \cdot 0 \%$, right colon $74 \cdot 1 \%$, transverse colon $66 \cdot 5 \%$, left colon $72 \cdot 8 \%$, rectum $74 \cdot 8 \%, n=12$ ), as has been reported for human faeces (Zoetendal et al., 1998). Non-inflamed and inflamed biopsy samples from the same patient gave profiles that were highly similar (UC, mean $91 \cdot 1 \%$, SEM $1 \cdot 4 \%$; CD, mean $90 \cdot 2 \%$, SEM $1 \cdot 7 \%$ ).

\section{Prevalence of selected bacterial groups detected by group-specific PCR}

DNA sequences originating from sulfate-reducing bacteria, Helicobacter species, or M. avium subsp. paratuberculosis were not detected in biopsy samples collected from healthy subjects or patients. One healthy transverse colon biopsy harboured $C$. difficile. This result was confirmed by elution and sequencing of the PCR product ( $100 \%$ identity, accession number X92982 C. difficile). Members of the Bacteroides/Prevotella group were detected in association with biopsies from $93 \%$ of healthy subjects and $92 \%$ of patients. Similarly, members of the C. coccoides group were commonly detected in healthy subjects $(92 \%)$ and IBD

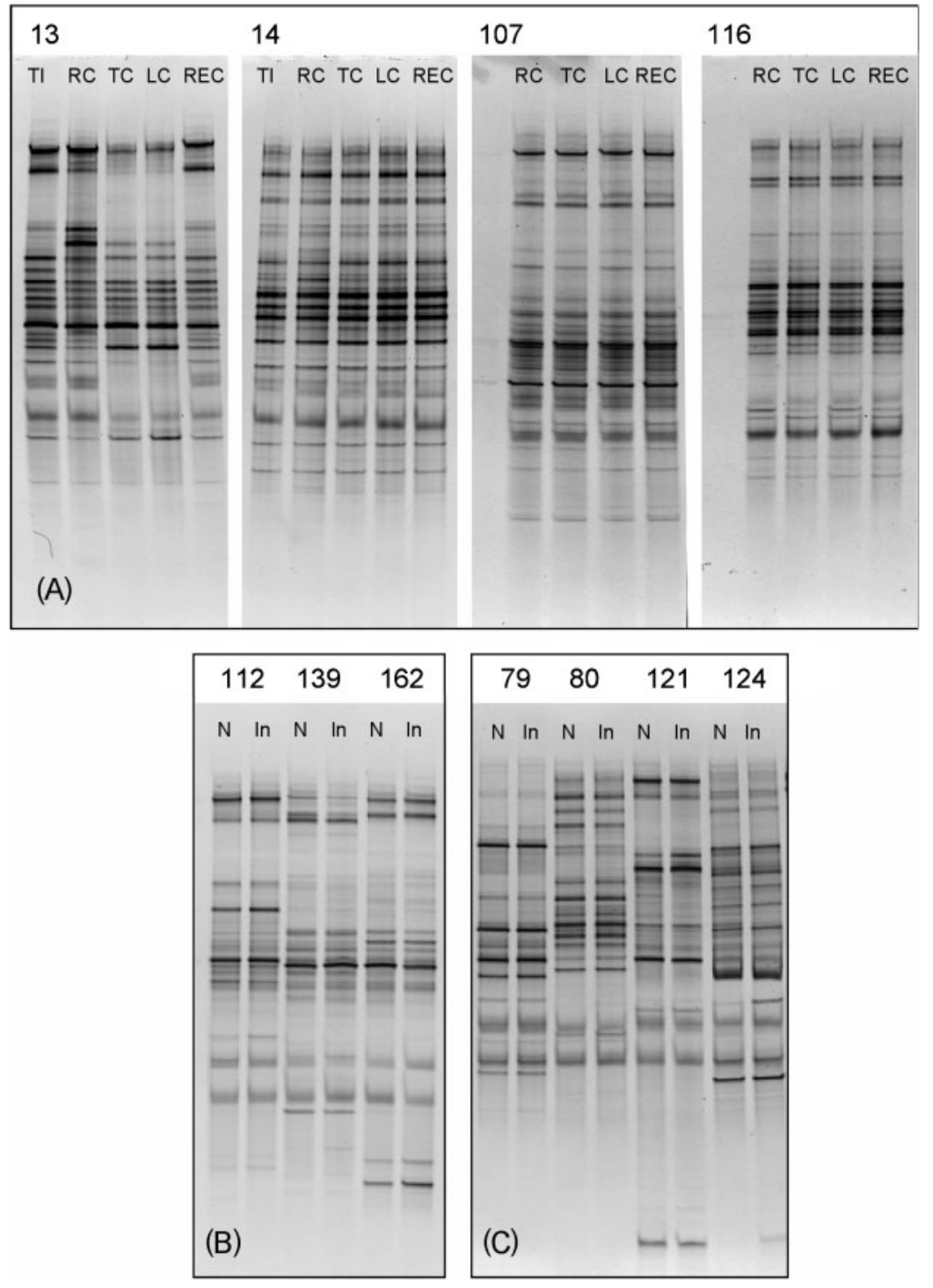

Fig. 1. Examples of PCR/DGGE profiles of bacterial collections associated with biopsies. These examples show the similarity of profiles obtained from different intestinal sites within individual subjects (A) and between inflamed and non-inflamed mucosa (B, C). (A) Healthy subjects; (B) CD patients; (C) UC patients. Abbreviations: TI, terminal ileum; $\mathrm{RC}$, right colon; TC, transverse colon; $\mathrm{LC}$, left colon; REC, rectum; $\mathrm{N}$, non-inflamed mucosa; In, inflamed mucosa. Subject numbers are shown. 
Table 4. OTU per library ( $3 \%$ distance level) and coverage

\begin{tabular}{|lccccc|}
\hline Library & $\begin{array}{c}\text { Total } \\
\text { clones }\end{array}$ & OTU & $\begin{array}{c}\text { Single-clone } \\
\text { OTU }\end{array}$ & $\begin{array}{c}\text { Coverage } \\
(\%)\end{array}$ & $\begin{array}{c}\text { Shannon } \\
\text { index }\end{array}$ \\
\hline Healthy & 235 & 99 & 50 & $78 \cdot 7$ & $4 \cdot 3$ \\
Non-inflamed CD & 374 & 132 & 80 & $78 \cdot 6$ & $4 \cdot 2$ \\
Inflamed CD & 435 & 153 & 91 & $79 \cdot 0$ & $4 \cdot 4$ \\
Non-inflamed UC & 305 & 102 & 58 & $80 \cdot 9$ & $4 \cdot 1$ \\
Inflamed UC & 386 & 138 & 68 & $82 \cdot 3$ & $4 \cdot 4$ \\
\hline
\end{tabular}

patients (UC, $77 \%$; CD, $90 \%$ ). Bifidobacteria were detected in $17 \%$ of healthy subjects and $26 \%$ of patients. Lactic acid bacteria seemed to be more prevalent in patients (UC, $97 \%$; CD, $90 \%$ ) compared to healthy subjects (69\%), but these results were not statistically significant (Fisher's exact test $P>0 \cdot 05)$.

\section{Enumeration of bacteria associated with biopsies}

UC patients had higher numbers of bacteria associated with biopsies than healthy subjects and CD patients (Fig. 2; Kruskal-Wallis non-parametric ANOVA, $P<0 \cdot 01)$. The results obtained from $C D$ and healthy subject samples did not differ $(P>0 \cdot 05)$. Bacterial numbers associated with non-inflamed and inflamed mucosa within $\mathrm{CD}$ and $\mathrm{UC}$ groups did not differ $(P>0 \cdot 05)$.

\section{Comparison of 16S rRNA gene clone libraries}

Coverage of the bacterial collections was similar for each library and averaged $80 \%$ (Table 4 ), thus providing a valid basis for inter-group library comparisons. LIBSHUFF analysis showed that the libraries prepared from inflamed or non-inflamed mucosa of CD patients did not differ, nor did

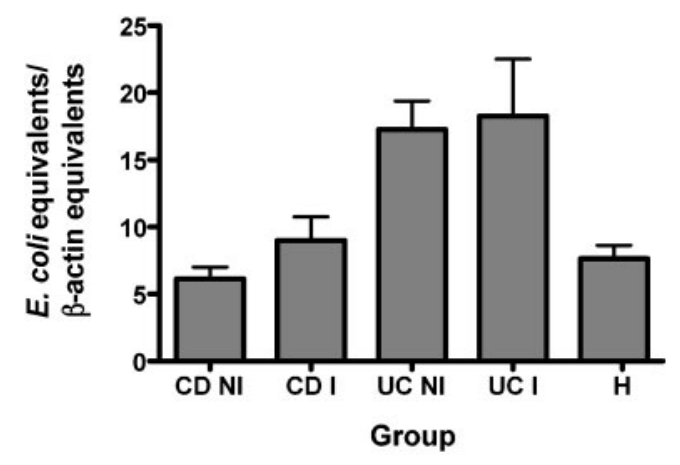

Fig. 2. Comparison of numbers of bacteria ( $E$. coli equivalents) associated with biopsies. Mean values and standard errors (bars) are shown. Abbreviations: CD, Crohn's disease patients; UC, ulcerative colitis patients; $H$, healthy subjects (all sites combined); NI, non-inflamed mucosa; I, inflamed mucosa. Fourteen, 11 and 33 biopsies were examined for the CD, UC and $\mathrm{H}$ groups, respectively. those generated from inflamed or non-inflamed mucosa of UC patients $(P>0 \cdot 05)$. In contrast, the libraries prepared from $\mathrm{CD}$ and UC patients, and libraries prepared from healthy subjects differed from each other $(P=0 \cdot 05)$.

DOTUR analysis indicated that the richness (bacterial diversity) tended to be similar for all groups (Shannon index; Table 4). Details of the classification of sequences in each library to bacterial phyla are given in Table 5. There was a trend for clones representing members of the phylum Bacteroidetes to be more prevalent in the libraries prepared from UC and CD patients compared to that of healthy subjects, but it was not statistically significant (Fishers exact test, $P>0 \cdot 05)$. Comparison of the prevalence of genera within the phylum Bacteroidetes, however, showed that unclassified Bacteroidetes were more prevalent in samples collected from CD patients than in those from healthy subjects or UC patients (Table 6; Fishers exact test, $P<0 \cdot 01)$. Unclassified members of the phylum Verrucomicrobia were only detected in biopsies from CD patients (Table 5), and unclassified Porphyromonadaceae from UC patients (Table 6).

\section{DISCUSSION}

A considerable amount of information about genetic and immunological aspects of CD and UC has been obtained in recent years (Podolsky, 2002; Bouma \& Strober, 2003). Yet knowledge of the microbiota-human interplay is incomplete, even though the bacterial community that inhabits the gut seems to play an important role in fuelling the chronic inflammation characteristic of IBDs (Macdonald \& Monteleone, 2005). The patients investigated in our study were newly diagnosed and had not yet received treatment for their disease. The bacteriological results that we have obtained therefore represent the bacteriology of untreated disease, whether CD or UC. Three methodical approaches were used to compare the nature of the collections of biopsyassociated bacteria: creating DGGE profiles of 16S rRNA gene sequences amplified from bacterial DNA extracted from the biopsies, preparing $16 \mathrm{~S}$ rRNA gene clone libraries whose sequences were compared, and PCR detection of selected bacterial groups known to be common in the human gut, reported to be aetiological agents of IBDs or putatively 'beneficial' bacteria. 
Table 5. Representation of bacterial phyla in 16S rRNA gene clone libraries

\begin{tabular}{|c|c|c|c|c|c|}
\hline Phylum & $\begin{array}{l}\text { Healthy } \\
(235)^{\star}\end{array}$ & $\begin{array}{c}\text { UC inflamed } \\
(386)\end{array}$ & $\begin{array}{c}\text { UC non- } \\
\text { inflamed (305) }\end{array}$ & $\begin{array}{c}\text { CD inflamed } \\
(435)\end{array}$ & $\begin{array}{c}\text { CD non- } \\
\text { inflamed (374) }\end{array}$ \\
\hline Actinobacteria & $3(1 \cdot 3) \dagger$ & $2(0 \cdot 5)$ & $0 \cdot 0$ & $3(0 \cdot 2)$ & $3(0 \cdot 8)$ \\
\hline Firmicutes & $121(52 \cdot 8)$ & $164(42 \cdot 2)$ & $166(54 \cdot 4)$ & $143(42 \cdot 8)$ & $142(38 \cdot 2)$ \\
\hline Fusobacteria & $0 \cdot 0$ & $0 \cdot 0$ & $1(0 \cdot 3)$ & $4(0 \cdot 5)$ & $4(1 \cdot 1)$ \\
\hline Unclassified Bacteria & $32(12 \cdot 8)$ & $42(12 \cdot 7)$ & $20(6 \cdot 6)$ & $52(20 \cdot 9)$ & $53(14 \cdot 2)$ \\
\hline Verrucomicrobia & 0 & 0 & 0 & $1(0 \cdot 2)$ & $2(0 \cdot 5)$ \\
\hline
\end{tabular}

${ }^{\star}$ Numbers in parentheses in the headings show the total number of clones.

$\nmid$ Values show the number of clones (percentage of total clones).

The numbers of bacteria associated with biopsies obtained from UC patients were approximately double those associated with samples from CD patients. This difference may reflect the altered nature of the mucus present on the mucosal surface of the colon of UC patients. The mucus is thinner and less sulphated than that of healthy subjects (Pullan et al., 1994; Corfield et al., 1996). The thinner layer may provide a more secure habitat for bacterial proliferation because the bacteria could be less likely to be dislodged by mucus flow. Alternatively or additionally, the bacteria might be more numerous because the non-sulphated mucins in the mucus are more easily degraded by bacterial cells and therefore provide an improved nutritional milieu (Roberton \& Corfield, 1999). A thin mucus layer containing larger than normal numbers of bacteria might facilitate contact between bacterial antigens and the mucosal immune system.

Although there was inter-subject diversity among the bacterial profiles associated with biopsies, just as there is in the case of the faecal microbiota (Zoetendal et al., 1998), pooling of $16 \mathrm{~S}$ rRNA gene clones from individuals of the same group provided an overview of the bacterial collections associated with each disease. The compositions of the bacterial collections associated with biopsies were different in each group of subjects: the 16S rRNA gene clone library of healthy subjects was different in composition from that of $\mathrm{CD}$ and UC patients. In turn, the libraries from CD patients differed in composition from those of UC subjects. These results clearly indicated that the bacteria associated with the mucosal surface were characteristic of a specific disease. These differences in bacterial composition were not due to the inflamed condition of the tissue, which might have altered the microbial ecology of the site, because bacterial collections associated with biopsies collected from inflamed and non-inflamed regions of the same gut did not differ in composition. Further, the biopsy-associated bacterial profile was highly conserved within subjects from whom biopsies were obtained from different regions of the intestinal tract. The differences between the bacterial collections were therefore real and not due to sampling artifacts. Pin-pointing bacterial species that are exclusively associated with $\mathrm{CD}$ or $\mathrm{UC}$ is still difficult, given the incomplete knowledge of the taxonomy of gut bacteria. Our study shows, however, that the altered prevalence of unclassified members of the

Table 6. Prevalence of groups detected within the phylum Bacteroidetes

\begin{tabular}{|lccc|}
\hline Phylogenetic group & Healthy (63)* & UC (234) $\dagger$ & CD (276) $\dagger$ \\
\hline Genus Bacteroides & $49(78 \cdot 0) \ddagger$ & $186(79 \cdot 5)$ & $208(75 \cdot 4)$ \\
Genus Chryseobacterium & 0 & $1(0 \cdot 4)$ & 0 \\
Genus Prevotella & $7(11 \cdot 0)$ & $7(3 \cdot 0)$ & $9(3 \cdot 3)$ \\
Genus Rikenella & $1(1 \cdot 5)$ & $9(3 \cdot 8)$ & $5(1 \cdot 8)$ \\
Unclassified order Bacteroidales & $5(8 \cdot 0)$ & $21(9 \cdot 0)$ & $26(9 \cdot 4)$ \\
Unclassified class Bacteroidetes & $1(1 \cdot 5)$ & $8(3 \cdot 4)$ & $28(10 \cdot 1)$ \\
Unclassified family Porphyromonadaceae & 0 & $2(0 \cdot 9)$ & 0 \\
\hline
\end{tabular}

${ }^{*}$ Total number of clones within phylum Bacteroidetes.

$\dagger$ Combined clones from inflamed and non-inflamed samples.

$\ddagger$ Values show the number of clones detected (percentage of total clones). 
phylum Bacteroidetes set the CD patients apart from other subjects. These bacteria therefore provide a target for future microbiological research concerning this disease. The qualitative PCR screen for M. avium subsp. paratuberculosis, Helicobacter species, C. difficile and sulfate-reducing bacteria did not support reports of their possible association with IBDs (Meyers et al., 1981; Gibson et al., 1991; Thompson, 1994; Ward et al., 1996; Tiveljung et al., 1999), nor did we detect a deficiency of lactic acid bacteria in patients relative to healthy subjects which might have indicated a need for 'probiotic' therapy (Macfarlane \& Cummings, 1999).

There is now considerable agreement between studies that UC is characterized by increased numbers of mucosaassociated bacteria (Schultsz et al., 1999; Kleessen et al., 2002; Swidsinski et al., 2002). Antibiotics are considered to have very limited usefulness in the treatment of UC (Podolsky, 2002), but, perhaps in the light of several bacteriological observations, the use of antibiotic preparations with pharmacological properties that target the mucosal surface of the colon would now be worthy of investigation. Specific bacterial targets for therapy of UC have not been identified by studies to date. LIBSHUFF analysis showed that the composition of the UC-derived library was different from that of healthy subjects, therefore further investigations may reveal suitable antimicrobial targets.

CD studies have produced variable reports, in which there was a lack of consistent association between particular bacteria and CD lesions (Prindiville et al., 2004), the loss of certain anaerobic bacteria present in control samples (Ott et al., 2004), and/or an increased number of mucosaassociated bacteria (Schultsz et al., 1999; Kleessen et al., 2002; Swidsinski et al., 2002). Our results from newly diagnosed patients show that the bacteriology of CD and UC is different, and that unclassified members of the phylum Bacteroidetes have a higher prevalence in CD. There is a need to move now to culture-based studies that specifically target these bacteria in order to study their antigenicity in relation to the immune systems of $\mathrm{CD}$ patients. If these bacteria continue to be refractory to cultivation, the application of metagenomics methodology will be appropriate, because this approach provides access to the genetics of complex bacterial communities of the gut even when most members are non-cultivable (Walter et al., 2005). While metagenomics has already been used to assess the biochemistry of bacterial communities (Handelsman, 2004), the gene pool that encodes the antigens to which the dysfunctional immune systems of IBD patients respond could equally well be investigated.

\section{ACKNOWLEDGEMENTS}

The support of the Crohn's and Colitis Foundation of Canada, and the excellent support of Dr Kevin McHugh and the Canadian IBD Network Tissue Bank Corporation are gratefully acknowledged. M. M. was supported by Fonterra Research, New Zealand, and G. T. by the Alberta Value Added Corporation, Canada. We thank Dr Leluo Guan for her assistance in the preparation of $16 \mathrm{~S}$ rRNA gene clone libraries.

\section{REFERENCES}

Beckwith, C. S., Franklin, C. L., Hook, R. R., Besch-Williford, C. L. \& Riley, L. K. (1997). Fecal PCR assay for diagnosis of Helicobacter infection in laboratory rodents. J Clin Microbiol 35, 1620-1623.

Bernhard, A. E. \& Field, K. G. (2000). Identification of nonpoint sources of fecal pollution in coastal waters by using host-specific $16 \mathrm{~S}$ ribosomal DNA genetic markers from fecal anaerobes. Appl Environ Microbiol 66, 1587-1594.

Bouma, G. \& Strober, W. (2003). The immunological and genetic basis of inflammatory bowel disease. Nat Rev Immunol 3, 521-533.

Collins, S. M., McHugh, K., Croitoru, K. \& Howorth, M. (2003). The establishment of a national tissue bank for inflammatory bowel disease research in Canada. Can J Gastroenterol 17, 107-109.

Corfield, A. P., Myerscough, N., Bradfield, N. \& 8 other authors (1996). Colonic mucins in ulcerative colitis: evidence for loss of sulphation. Glycoconj J 13, 809-822.

Deplancke, B., Hristova, K. R., Oakley, H. A., McCracken, V. J., Aminov, R., Mackie, R. I. \& Gaskins, H. R. (2000). Molecular ecological analysis of the succession and diversity of sulfate-reducing bacteria in the mouse gastrointestinal tract. Appl Environ Microbiol 66, 2166-2174.

Dove, C. H., Wang, S. Z., Price, S. B., Phelps, C. J., Lyerly, D. M., Wilkinds, T. D. \& Johnson, J. L. (1990). Molecular characterization of the Clostridium difficile toxin A gene. Infect Immun 58, 480-488.

Gibson, G. R., Cummings, J. H. \& Macfarlane, G. T. (1991). Growth and activities of sulphate-reducing bacteria in gut contents of healthy subjects and patients with ulcerative colitis. FEMS Microbiol Ecol 86, 103-112.

Good, I. J. (1953). The population frequencies of species and the estimation of population parameters. Biometrica 40, 237-264.

Handelsman, J. (2004). Metagenomics: application of genomics to uncultured microorganisms. Microbiol Mol Biol Rev 68, 669-685.

Hughes, J. B. \& Bohannan, B. J. M. (2004). Application of ecological diversity statistics in microbial ecology. In Molecular Microbial Ecology Manual, vol. 2, 2nd edn, pp. 1321-1344. Edited by G. A. Kowalchuk, F. J. de Bruijn, I. M. Head, A. D. L Akkermans \& J. D. van Elsas. Dordrecht: Kluwer Academic Publishers.

Kleessen, B., Kroesen, A. J., Buhr, H. J. \& Blaut, M. (2002). Mucosal and invading bacteria in patients with inflammatory bowel disease compared with controls. Scand J Gastroenterol 37, 1034-1041.

Kok, R. G., De Waal, A., Schut, F., Welling, G. W., Weenk, G. \& Hellingwerf, K. J. (1996). Specific detection and analysis of a probiotic Bifidobacterium strain in infant feces. Appl Environ Microbiol 62, 3668-3672.

Lepage, P., Seksik, P., Sutren, M., de la Cochetiere, M. F., Jian, R., Marteau, P. \& Doré, J. (2005). Biodiversity of the mucosa-associated microbiota is stable along the distal digestive tract in healthy individuals and patients with IBD. Inflamm Bowel Dis 11, 473-480.

MacDonald, T. T. \& Monteleone, G. (2005). Immunity, inflammation, and allergy in the gut. Science 307, 1920-1925.

Macfarlane, G. T. \& Cummings, J. H. (1999). Probiotics and prebiotics: can regulating the activities of intestinal bacteria benefit health? BMJ 318, 999-1003.

Matsuki, T., Watanabe, K., Fujimoto, J., Miyamoto, Y., Takada, T., Matsumoto, K., Oyaizu, H. \& Tanaka, R. (2002). Development of $16 \mathrm{~S}$ rRNA-gene-targeted group-specific primers for the detection and identification of predominant bacteria in human feces. Appl Environ Microbiol 68, 5445-5451.

Meyers, S., Mayer, L., Bottone, E., Desmond, E. \& Janowitz, H. D. (1981). Occurrence of Clostridium difficile toxin during the course of inflammatory bowel disease. Gastroenterology 80, 697-690. 
Moore, W. E. C., Cato, E. P. \& Holdeman, L. V. (1978). Some current concepts in intestinal bacteriology. Am J Clin Nutr 31, S33-S42.

Nadkarni, M. A., Martin, F. E., Jacques, N. A. \& Hunter, N. (2002). Determination of bacterial load by real-time PCR using a broadrange (universal) probe and primers set. Microbiology 148, 257-266. Naser, S. A., Ghabrial, G., Romero, C. \& Valentine, J. F. (2004). Culture of Mycobacterium avium subspecies paratuberculosis from the blood of patients with Crohn's disease. Lancet 364, 1039-1044.

Ott, S. J., Musfeldt, M., Wenderoth, D. F., Hampe, J., Brant, O., Folsch, U. R., Timmis, K. N. \& Schreiber, S. (2004). Reduction in diversity of the colonic mucosa associated bacterial microflora in patients with active inflammatory bowel disease. Gut 53, 685-693.

Podolsky, D. K. (2002). Inflammatory bowel disease. N Engl J Med 347, 417-428.

Prindiville, T., Cantrell, M. \& Wilson, K. H. (2004). Ribosomal DNA sequence analysis of mucosa-associated bacteria in Crohn's disease. Inflamm Bowel Dis 10, 824-833.

Pullan, R. D., Thomas, G. A. O., Rhodes, M., Newcombe, R. G., Williams, G. T., Allen, A. \& Rhodes, J. (1994). Thickness of adherent mucus gel on colonic mucosa in humans and its relevance to colitis. Gut 35, 353-359.

Roberton, A. M. \& Corfield, A. P. (1999). Mucin degradation and its significance in inflammatory conditions of the gastrointestinal tract. In Medical Importance of the Normal Microflora, pp. 222-261. Edited by G. W. Tannock. Dordrecht: Kluwer Academic Publishers.

Rodtong, S. \& Tannock, G. W. (1993). Differentiation of Lactobacillus strains by ribotyping. Appl Environ Microbiol 59, 3480-3484.

Ruseler-Van Embden, J. G. H. \& Both-Patoir, H. C. (1983). Anaerobic Gram-negative faecal flora in patients with Crohn's disease and healthy subjects. Antonie van Leeuwenhoek 49, 125-132.

Schloss, P. D. \& Handelsman, J. (2005). Introducing DOTUR, a computer program for defining operational taxonomic units and estimating species richness. Appl Environ Microbiol 71, 1501-1506.

Schultsz, C., van den Berg, F., Ten Kate, F. W., Tytgat, G. N. \& Dankert, J. (1999). The intestinal mucus layer from patients with inflammatory bowel disease harbors high numbers of bacteria compared with controls. Gastroenterology 117, 1089-1097.

Schultz, M. \& Rath, H. C. (2002). The possible role of probiotic therapy in inflammatory bowel disease. In Probiotics and Prebiotics: Where Are We Going?, pp. 175-237. Edited by G. W. Tannock. Wymondham, UK: Caister Academic Press.

Sechi, L. A., Mura, M., Tanda, F., Lissia, A., Solinas, A., Fadda, G. \& Zanetti, S. (2001). Identification of Mycobacterium avium subsp. paratuberculosis in biopsy specimens from patients with Crohn's disease identified by in situ hybridization. J Clin Microbiol 39, 4514-4517.

Seksik, P., Rigottier-Gois, L., Gramet, G., Sutren, M., Pochart, P., Marteau, P., Jian, R. \& Dore, J. (2003). Alterations of the dominant faecal bacterial groups in patients with Crohn's disease of the colon. Gut 52, 237-242.

Singleton, D. R., Furlong, M. A., Rathbun, S. L. \& Whitman, W. B. (2001). Quantitative comparisons of $16 \mathrm{~S}$ rRNA gene sequence libraries from environmental samples. Appl Environ Microbiol 67, 4374-4376.

Stebbings, S., Munro, K., Simon, M. A. \& 8 other authors (2002). Comparison of the faecal microflora of patients with ankylosing spondylitis and controls using molecular methods of analysis. Rheumatology 41, 1395-1401.

Swidsinski, A., Ladhoff, A., Pernthaler, A. \& 8 other authors (2002). Mucosal flora in inflammatory bowel disease. Gastroenterology 122, 44-54.

Tannock, G. W., Munro, K., Harmsen, H. J. M., Welling, G. W., Smart, J. \& Gopal, P. K. (2000). Analysis of the fecal microflora of human subjects consuming a probiotic containing Lactobacillus rhamnosus DR20. Appl Environ Microbiol 66, 2578-2588.

Thompson, D. E. (1994). The role of mycobacteria in Crohn's disease. J Med Microbiol 41, 74-94.

Thorel, M.-F., Krichevsky, M. \& Levy-Frebault, V. V. (1990). Numerical taxonomy of mycobactin-dependent mycobacteria, emended description of Mycobacterium avium, and description of Mycobacterium avium subsp. avium subsp. nov., Mycobacterium avium subsp. paratuberculosis subsp. nov., and Mycobacterium avium subsp. silvaticum subsp. nov. Int J Syst Bacteriol 40, 254-260.

Tiveljung, A., Soderholm, J. D., Olaison, G., Jonasson, J. \& Monstein, H.-J. (1999). Presence of eubacteria in biopsies from Crohn's disease inflammatory lesions as determined by $16 \mathrm{~S}$ rRNA gene-based PCR. J Med Microbiol 48, 263-268.

Walter, J., Hertel, C., Tannock, G. W., Lis, C. M., Munro, K. \& Hammes, W. P. (2001). Detection of Lactobacillus, Pediococcus, Leuconostoc, and Weissella species in human feces by using groupspecific PCR primers and denaturing gradient gel electrophoresis. Appl Environ Microbiol 67, 2578-2585.

Walter, J., Mangold, M. \& Tannock, G. W. (2005). Construction, analysis, and $\beta$-glucanase screening of a bacterial artificial chromosome library from the large bowel of mice. Appl Environ Microbiol 71, 2347-2354.

Ward, J. M., Anver, M. R., Haines, D. C., Melhorn, J. M., Gorelick, P., Yan, L. \& Fox, J. G. (1996). Inflammatory large bowel disease in immunodeficient mice naturally infected with Helicobacter hepaticus. Lab Anim Sci 46, 15-20.

Zimmer, R. \& Gibbins, A. M. (1997). Construction and characterization of a large-fragment chicken bacterial artificial chromosome library. Genomics 42, 217-226.

Zoetendal, E., Akkermans, A. D. \& DeVos, W. M. (1998). Temperature gradient gel electrophoresis analysis of 16S rRNA from human fecal samples reveals stable and host-specific communities of active bacteria. Appl Environ Microbiol 64, 3854-3859.

Zoetendal, E. G., von Wright, A., Vilpponen-Salmela, T., Ben-Amor, K., Akkermans, A. D. L. \& De Vos, W. M. (2002). Mucosa-associated bacteria in the human gastrointestinal tract are uniformly distributed along the colon and differ from the community recovered from feces. Appl Environ Microbiol 68, 3401-3407. 